\title{
PERAN KOMITE MADRASAH DALAM MEMBANTU MENGEMBANGKAN SARANA PRASARANA DI MADRASAH ALIYAH NEGERI 2 PAMEKASAN
}

\author{
Laily Mutohharoh \\ Universitas Islam Negeri Maulana Malik Ibrahim Malang \\ Email: Lailymutohharoh123@gmail.com
}

\begin{abstract}
Abstrak
Di dalam satuan pendidikan seperti madrasah, keberadaan komite madrasah menjadi suatu hal yang sangat penting. Penelitian ini bertujuan untuk mendeskripsikan tentang peran komite madrasah dalam membantu mengembangkan sarana prasarana di MAN 2 Pamekasan, dengan sub fokus mencakup: (1) konsep pengembangan sarana prasarana, (2) pelaksanaan pengembangan sarana prasarana, (3) implikasi pengembangan sarana prasarana, yang dilakukan di Madrasah Aliyah Negeri 2 Pamekasan. Penelitian ini menggunakan pendekatan kualitatif dengan jenis studi kasus. Hasil penelitian ini menunjukkan bahwa: 1) konsep pengembangan saranaprasarana dilakukan dengan menetapkan tujuan terlebih dahulu dan membuat program kerja komite madrasah, 2) pelaksanaan pengembangan sarana prasarana dilaksanakan dengan komite madrasah berperan sebagai pemberi pertimbangan, sebagai pendukung, sebagai pengontrol dan sebagai mediator, 3) implikasi yang dirasakan dari pengembangan sarana prasarana yaitu semakin meningkatnya jumlah sarana prasarana yang dimiliki oleh madrasah yang sekarang sudah sesuai standarisasi sarana prasarana yang sudah ditentukan.
\end{abstract}

Kata Kunci : Peran, Komite Madrasah, Sarana Prasarana

\begin{abstract}
In educational units such as madrasas, the existence of madrasa committees is very important. This study aims to describe the role of the madrasah committee in helping to develop infrastructure at MAN 2 Pamekasan, with sub-focuses including (1) the concept of infrastructure development, (2) the implementation of infrastructure development, (3) the implications of infrastructure development, carried out at Madrasah Aliyah Negeri 2 Pamekasan. This research uses a qualitative approach with the type of case study. The results of this study indicate that: 1) the concept of infrastructure development is carried out by setting goals in advance and making a madrasa committee work program, 2) the implementation of infrastructure development is carried out with the madrasa committee acting as a giver of consideration, as a supporter, as a controller and as a mediator, 3) The perceived implication of the development of infrastructure facilities is the increasing number of infrastructure facilities owned by madrasas which are now by the standardization of infrastructure facilities that have been determined.
\end{abstract}

Keywords : Role, Madrasah Committee, Facilities and Infrastructure 


\section{PENDAHULUAN}

Dewasa ini pendidikan merupakan sebuah cara terbaik dalam menghantarkan kemajuan suatu bangsa dan negara. Dalam hal ini dunia pendidikan mempunyai peran sangat strategis dalam mencerdaskan kehidupan bangsa, tidak ada kemajuan suatu bangsa tanpa ada peran pendidikan didalamnya. Hal ini sudah dijamin oleh sistem perundang-undangan. Dalam pembukaan UUD 1945 menyatakan bahwa salah satu tujuan Negara Kesatuan Republik Indonesia yaitu mencerdaskan kehidupan bangsa.

Pemerintah dalam rangka melunasi cita-cita tersebut, menjadikan pendidikan sebagai wadah utama dalam menimba ilmu pengetahuan. Sehingga pemerintah terus menerus melakukan peningkatan dan pemerataan dengan mendirikan lembaga-lembaga pendidikan di daerah perkotaan hingga daerah pedesaan.

Peningkatan mutu pendidikan pada pendidikan formal diperlukan suatu Komite Madrasah untuk memberikan sumbangsih ide dan kontrol terhadap pelaksanaan pendidikan. Selain itu dibutuhkan juga sebuah planning pendidikan yang sistematis dan akurat terhadap perkembangan pendidikan di madrasah melalui kerjasama dengan tokoh masyarakat yang berada dalam wadah formal yang biasa disebut Komite Madrasah. ${ }^{1}$

Keberhasilan dalam sebuah lembaga pendidikan tergantung pada manajemen yang diterapkan dalam sebuah lembaga tersebut. Sekaligus peran manajer dalam menganut sistem manajemen, organisasi pendidikan serta perencanaan pendidikan agar menjadi lingkungan pendidikan yang kondusif. Karena jika manajemen yang dikelola itu sangat baik maka hasil yang akan dicapai dalam pendidikan tersebut akan berjalan dengan efektif dan mengahasilkan sebuah keberhasilan. ${ }^{2}$

Banyak pakar pendidikan berpendapat bahwa yang sangat menentukan dalam keberhasilan program pendidikan adalah adanya guru sebagai sumber daya manusia. Namun, tidak hanya itu. Adanya unsur lain seperti sarana prasarana juga tidak bisa dilupakan. Dalam rangka meningkatkan mutu pendidikan di madrasah perlu adanya manajemen sarana prasarana pendidikan yang baik sebagai penunjang terlaksananya mutu pembelajaran di madrasah. ${ }^{3}$

UU No. 20 Tahun 2003 tentang Sistem Pendidikan Nasional pada pasal 45 menyatakan bahwa: "Setiap satuan pendidikan formal dan nonformal menyediakan sarana prasarana yang memenuhi keperluan pendidikan sesuai dengan pertumbuhan dan perkembangan potensi fisik, kecerdasan intelektual, sosial, emosional, dan kejiwaan peserta didik". ${ }^{4}$ Tapi, pada kenyataannya secara umum masih banyak kendala yang dihadapi madrasah dalam mengembangkan sarana prasarana pendidikan. Adapun kendala-kendala yang dihadapi madrasah dalam mengembangkan sarana prasarana yaitu: terbatasnya biaya, adanya sarana prasarana yang tidak sesuai dengan kebutuhan madrasah, tidak seimbangnya jumlah sarana prasarana dengan jumlah peserta didik dan guru dimadrasah tersebut.

\footnotetext{
${ }^{1}$ Mulyono, Manajemen Administrasi dan Organisasi Pendidikan,(Jogjakarta:Arruz-Media,2014), 258260.

2 Atiqullah and Milda Karya Puspasari, "STRATEGI MANAJEMEN PERUBAHAN DALAM MENINGKATKAN KUALITAS MANAJERIAL PENDIDIKAN ISLAM DI MAN 1 PAMEKASAN," Re-JIEM (Research Journal of Islamic Education Management) 1, no. 2 (2018): 15, https://doi.org/https://doi.org/10.19105/rjiem.v1i2.2088.

3 Ibrahim Bafadal, Manajemen Perlengkapan Sekolah (Jakarta: PT. Bumi Aksara, 2010). Cet. $2,1$.

${ }^{4}$ Ara Hidayat \& Imam Machali, Pengelolaan Pendidikan: Konsep, Prinsip, dan Aplikasi dalam Mengelola Sekolah dan Madrasah (Yogyakarta: Kaukaba, 2012), Cet. 1, 155.
} 
Kendala ini bisa terjadi karena kurangnya rasa sadar seluruh komponen yang ada di madrasah tentang betapa pentingnya pengembangan sarana prasarana pendidikan secara tepat, khususnya komite madrasah. Masih banyak komite madrasah yang kurang sadar terhadap pendidikan terutama dalam membantu mengembangkan sarana prasarana pendidikan secara tepat. Padahal madrasah bisa dikatakan bermutu salah satunya dilihat dari kelengkapan sarana prasarana yang ada didalamnya.

Komite madrasah sebagai organisasi mandiri yang mewadahi peran serta masyarakat memiliki tugas untuk selalu meningkatkan kualitas madrasah. Karena melihat dari kualitas, pendidikan di Indonesia belum mampu memenuhi kebutuhan serta tantangan nasional maupun global. ${ }^{5}$ Masalah mutu pendidikan selalu diperbincangkan oleh politisi, masyarakat, orangtua serta pendidik. Karena tidak bisa dipungkiri bahwa di Indonesia mutu pendidikan masih jauh dari harapan jika dibandingkan dengan Negara lain. Pada tahun 2000 Survey dari Political and Economic Risk Consultancy (PERC) mengenai mutu pendidikan di kawasan Asia menyatakan bahwa Indonesia berada di peringkat 12 setingkat dibawah Vietnam. ${ }^{6}$

Usaha pemerintah dalam menjamin mutu juga ditetapkan dalam Peraturan Menteri Pendidikan Nasional No. 24 Tahun 2017 tentang Standar Sarana dan Prasarana Pendidikan untuk SD/MI, SMP/MTS, SMA/MA. Minimumnya criteria sarana terdiri atas media pendidikan, perabot, peralatan pendidikan, buku serta sumber belajar lainnya, teknologi informasi serta perlengkapan lainnya yang wajib dimiliki oleh setiap madrasah. Sedangkan sarana nya terdiri dari lahan, gedung, ruangan, serta anggaran dana yang wajib dimiliki oleh setiap madrasah. ${ }^{7}$

MAN 2 Pamekasan merupakan madrasah yang berdiri dibawah naungan menteri agama ini bisa menarik perhatian dari masyarakat dengan menunjukkan madrasah yang unggul dibuktikan dengan berbagai macam prestasi yang diraih setiap tahunnya yang selalu mengalami peningkatan. Tak hanya itu, MAN 2 Pamekasan memiliki keunikan diantara madrasah lain yaitu mempunyai program Pendidikan setara Diploma 1 yang bekerjasama dengan ITS Surabaya Jurusan Komputer yang dilaksanakan pada sore hari.

Dalam rangka itu, riset dan evaluasi sebagai bahan kajian perlu dilakukan terus menerus. Terkait dengan tindakan ini, peneliti menetapkan MAN 2 Pamekasan menjadi lokasi penelitian. Karena berdasarkan penelitian awal pada MAN 2 Pamekasan diperoleh informasi sebagai berikut: ${ }^{8}$ Komite madrasah di MAN 2 Pamekasan sudah terbentuk dan berjalan dengan lancar sejak tahun 1992 seiring beralihnya MAN 2 Pamekasan yang sebelumnya masih PGAN, Keberadaan komite madrasah yang dominan dalam usaha mendapatkan dana dan pengembangan sarana prasarana di MAN 2 Pamekasan. Dana yang didapatkan sebesar 50.000.000,- setiap bulan nya yang diperoleh dari infaq bulanan dan infaq insidentil dari wali santri dan Kedekatan komite madrasah dengan kepala madrasah, guru dan masyarakat dalam rangka perencanaan pembuatan Rencana Program Madrasah (RPS) dan Rencana Anggaran Pendapatan Belanja Madrasah (RAPBS) di MAN 2 Pamekasan.

Melihat fenomena tersebut, peran dan fungsi komite madrasah dalam membangun, mengembangakan, dan mewujudkan madrasah yang bemutu sangatlah

\footnotetext{
5 Abdul Hadis\& Nurhayati, Manajemen Mutu Pendidikan (Bandung: Alfabeta, 2010), 68.

${ }^{6}$ Abdul Hadis\& Nurhayati, Manajemen Mutu Pendidikan, 1.

${ }^{7}$ Matin, Manajemen Sarana Prasarana (Jakarta: PT Raja Grafindo, 2017), 15

${ }^{8}$ Arifa'i, S.Ag, wawancara (Pamekasan, 10 Januari 2020).
} 
diperlukan karena peran komite sebagai supervisi madrasah selalu menjadi pengontrol terhadap keberlangsungan madrasah tersebut. Maka dari itu peneliti tertarik untuk melakukan penelitian dengan judul Peran Komite Madrasah dalam Membantu Mengembangkan Sarana Prasarana (Studi Kasus di MAN 2 Pamekasan).

\section{METODE PENELITIAN}

Penelitian ini menggunakan pendekatan kualitatif. Menurut kutipan Corbin dan Strauss pendekatan kualitatif adalah konsep penelitian yang menghasilkan data deskriptif berupa tulisan dan ucapan yang diperoleh dari informan dan perilaku yang diamati. ${ }^{9}$ Jenis penelitian kualitatif ini adalah studi kasus sebagaimana diungkapkan oleh Yin "studi kasus merupakan penyelidikan empiris kontemporer dalam konteks kehidupan nyata, terutamaa ketika batas-batas antara fenomena dan konteks tidak begitu jelas". Penelitian ini dipilih untuk membantu mengeksplorasi pengalaman komte madrasah dalam berpartisipasi membantu mengembangkan saranaa prasarana di maadrasah.

Dalam penelitian kualitatif, kehadiran peneliti sebagai sesuatu yang sangat penting dan wajib dilakukan. Hadirnya peneliti selainsebagai misi menyambung komunikasi dan silaturrahim dengan informan, juga untuk memperoleh data dan informasi yang dibutuhkan sesuai dengan fokus yang diteliti. Dengan hadirnya peneliti di tempat penelitian, peneliti akan menguasai keadaan, situasi dan kondisi di lapangan.

Peneliti berperan sebagai instrument atau penghimpun data dan sekaligus menjadi observer. Sebagai observatory, peneliti pemrogram dalam mengambil data, menganalisis dan melaporkan hasil penelitian. Sebagai instrument, peneliti sebagai alat yang melibatkan langsung seluruh proses penelitian, sehingga validitas dan keabsahan data terjamin kebenarannya.

Lokasi dalam penelitian ini yang menjadi objek penelitian adalah MAN 2 Pamekasan. Peneliti mengambil lokasi tersebut dengan alasan lokasi penelitian ini merupakan madrasah yang memiliki brand madrasah favorit dan mendapat kepercayaan dari masyarakat. Dimana madrasah bersaing untuk memberikan kualitas pendidikan.

Sumber data dari penelitian ini adalah data tertulis dan ucapan. Data tersebut dibagi 2 macam yaitu: data primer dan sekunder. Dalam penelitian kualitatif Data primer adalah sumber data utama yang berupa kata dan aktivitas yang diperoleh secara langsung dari sumber utama. Sumber data sekunderadalah data yang bukan bersumber dari manusia, akan tetapi data pendukung seperti foto kegiatan komite madrasah. sumber data sekunder digunakan sebagai arsip atau bahan bacaan yang memuat hal-hal yang ada hubungannya dengan tujuan penelitian sehingga peneliti bisa mengumpulkan dan mengambilnya.

Kegiatan pengumpulan data dilakukan dengan beberapa prosedur seperti observasi, wawancara dan dokumentasi. Anlisis data dalam penelitian kualitatif jika melihat model Miles dan Huberman adalah reduksi data, penyajian data dan verifikasi.

Meleong menjelaskan, "temuan penelitian dipakai untuk keperluan kebijaksanaan dan perencanaan layanan adalah kemungkinan lain bagi pengecekan kevalidan data". ${ }^{10}$ Agar bisa mengecek valid nya data yang dihasilkan di lapangan, maka peneliti

\footnotetext{
9 Anselm Strauss dan Juliet Corbin, Dasar-dasar Penelitian Kualitatif (Yogyakarta: Pustaka Pelajar, 2005), 5.

10 Lexy.J. Meleong, Metode Penelitian Kualitatif (Bandung: Rosdakarya, 2005), 300
} 
mengecek data dengan menggunakan teknik sebagai brikut: credibility, transferability, dependability, dan confirmability.

Pada tingkat kepercayaan banyak cara untuk meningkatkan kredibilitas data yang diperoleh untuk mengukur keabsahan hasil penelitian, yaitu: lamanya waktu pengamatan, ketekunan pengamatan, triangulasi.

\section{HASIL DAN PEMBAHASAN}

Berdasarkan fokus latar permasalahan di atas, maka diperlukan aktualisasi yang terdiri dari tiga fokus penelitian, sehingga temuan penelitian ditemukan sebagai berikut:

\section{Konsep Komite Madrasah dalam Membantu Mengembangkan Sarana Prasarana di MAN 2 Pamekasan}

Secara universal partisipasi masyarakat untuk meningkatkan kualitas pendidikan di lingkungan madrasah belum bermakna. Tingkat partisipasi masyarakat bisa diukur dari berapa banyak sumbangan yang disumbangkan oleh masyarakat baik itu material maupun dana dalam rangka pembangunan dan pengembangan fisik madrasah.

Komite madrasah merupakan sebuah organisasi mandiri yang memberi wadah terhadap peran serta masyarakat dalam rangka meningkatkan mutu, pemerataan dan efesiensi pengelolaan pendidikan di Satuan Pendidikan baik pada pendidikan pra madrasah, jalur pendidikan madrasah maupun jalur pendidikan luar madrasah. Keberadaan komite madarasah tersebut sudah ditetapkan secara legal dalam keputusan menteri pendidikan nasional nomor 044/U/2002. ${ }^{11}$

Komite madrasah di MAN 2 Pamekasan didirikan dengan tujuan dan meningkatkan peran serta masyarakat dalam dunia pendidikan. Madrasah dalam menentukan kebijakan tidak bisa berdiri sendiri terutama dalam hal pembiayaan pendidikan, akan tetapi harus melakukan kerjasama yang baik dengan komite madrasah. Sebagaimana KepMenDikNas No 044/U/2001 yang dikutip oleh Abdul Rahmat dalam bukunya yang mana tujuan komite madrasah sebagai berikut: ${ }^{12}$ Pertama, mewadahi dan menyalurkan aspirasi dan prakarsa masyarakat dalam melahirkan kebijakan operasional dan program pendidikan di madrasah. Kedua, meningkatkan tanggungjawab dan peran serta masyarakat dalam penyelenggaraan pendidikan di madrasah. Ketiga, menciptakan suasana dan kondisi transparan, akuntabel, dan demokratis dalam penyelenggaraan dan pelayanan pendidikan yang bermutu di madrasah.

Setelah komite madrasah didirikan, maka komite madrasah membuat perencanaan program kerjanya. Karena kinerja komite madrasah dalam membantu meningkatkan mutu terutama dalam hal mengembangkan sarana prasarana tidak akan terlepas dari yang namanya perencanaan. Karena perencanaan merupakan kegiatan yang akan dilaksanakan dimasa yang akan datang untuk mencapai tujuan tertentu.

Dalam melaksanakan perencanaan komite MAN 2 Pamekasan selalu melibatkan kepala madrasah, waka sarana prasarana dan semua tenaga pendidik dan tenaga kependidikan lainnya. Semua itu dilakukan karena kepala madrasah, waka sarana prasarana, tenaga pendidik dan tenaga kependidikan lainnya yang mengetahui

11 Hasbullah, Otonomi Pendidikan: Kebijakan Otonomi Daerah dan Implikasinya terhadap Penyelenggaraan Pendidikan (Jakarta: Rajawali Pers, 2007), 89.

12 Abdul Rahmat, Manajemen Humas Sekolah (Yogyakarta, Media Akademi, 2016), 107. 
langsung yang sedang terjadi di madrasah. Dengan adanya mereka, sangat penting adanya masukan kritikan dan pendapat lainnya terhadap program kerja komite selama satu tahun untuk dimusyawarahkan bersama sehingga semua warga madrasah memiliki jiwa yang besar untuk berusaha menjaga sarana prasarana.

Dalam rencana program komite MAN 2 Pamekasan dalam membantu mengembangkan sarana prasarana terlebih dahulu melihat kebutuhan apa yang paling urgent selama satu tahun kedepan dengan meminta pendapat dari waka sarana prasarana yang tahu persis tentang keadaan dilapangan.. Salah satu contohnya di MAN 2 Pamekasan, mengenai penambahan gedung asrama untuk siswa program tahfidz, perbaikan kursi jika ada yang rusak.

\section{Pelaksanaan Peran Komite Madrasah dalam rangka Membantu Mengembangkan Sarana Prasarana Pendidikan di MAN 2 Pamekasan}

Dalam pelaksanaan program kerja komite membutuhkan perencanaan yang matang sehingga tujuan yang diinginkan tercapai sesuai sasaran. Dalam pelaksanaan program kerjanya komite madrasah di MAN 2 Pamekasan menjalankan peran sebagai komite sebagai berikut : Pertama, sebagai pemberi pertimbangan (advisory agency), berdasarkan hasil penelitian komite madrasah yang ada di MAN 2 Pamekasan sudah memberikan pertimbangannya dalam setiap program dan rencana madrasah yang telah disusun bersama, pertimbangan yang diberikan oleh komite madrasah berupa pemikiran/ide, saran serta pertimbangan tentang cara yang digunakan dalam pengadaan sarana prasarana yang berhubungan langsung maupun tidak langsung terhadap peningkatan kualitas pendidikan. Tak hanya itu dalam penetapan RAPBS komite madrasah ikut dilibatkan. Karena masukan dan pertimbangan dari komite madrasah sangat dibutuhkan karena di RAPBS juga ada tanda tangan komite madrasah.

Terkait hal tersebut Eni Wahyuningsih dalam jurnalnya juga menyatakan peran komite sekolah di SDN Serayu sebagai pemberi pertimbangan (advisory Agency) dalam mengelola sarana prasarana pembelajaran dilakukan dengan cara menghadiri rapat dalam penyusunan RAPBS, memberi ide, saran serta pertimbangan dalam proses perencanaan sarana prasarana pembelajaran yang mana pertimbangan yang diberikan tentang cara yang baik untuk digunakan dalam proses pengadaan sarana prasarana sekolah. ${ }^{13}$

Selain pertimbangan-pertimbangan yang sudah disebut diatas, komite di MAN 2 Pamekasan Komite MAN 2 Pamekasan juga menentukan skala prioritas terhadap sarana prasarana yang dibutuhkan di madrasah dengan mengidentifikasi sarana prasarana apa saja yang dibutuhkan oleh madrasah dan diseleksi pada bagian sarana prasarana yang perlu di perbaiki atau melakukan pengadaan baru. Selanjutnya antara pihak komite madrasah bersama madrasah bersama-sama menentukan prioritas agar segera melakukan perbaikan ataupun pengadaan baru pada sarana-prasarana yang menjadi prioritas utama di madrasah. Terutama yang paling prioritas yang menunjang proses pembelajaran.

13 Eni Widyaningsih, "Peran Komite Sekolah dalam Pengelolaan Sarana Prasarana Pembelajaran di SDN Serayu", Jurnal Pendidikan Guru Sekolah Dasar. 10 (2016), 983. 
Orientasi komite madrasah tidak selalu pada uang, akan tetapi juga pada hal yang bisa diadakan bersama, misalnya membentuk system pembelajaran yang baik, membantu menambahkan sarana prasarana jika dibutuhkan, dan kegiatan lain yang dapat dikerjakan bersama. Temuan penelitian Komite madrasah di MAN 2 Pamekasan melakukan pertemuan terjadwal untuk menampung dan membahas semua kebutuhan di madrasah, Menarik bantuan dari masyarakat terutama wali santri dalm bentuk SPP, Memberi bantuan secara fisik yang berupa lcd pada masingmasing kelas sebagai bentuk upaya komite madrasah dalam membantu mengembangkan sarana prasarana.

Oleh karena itu pendapat Satori yang dikutip oleh syaiful sagala bahwa kontribusi dari komite madrasah terhadap madrasah bisa dilakukan dengan mengadakan pertemuan terjadwal untuk menampung serta membahas kebutuhan, masalah, aspirasi, maupun ide dari komite madrasah. memikirkan upaya-upaya yang akan dilakukan dalam rangka memajukan madrasah terutama dalam hal kelengkapan fasilitas madrasah, fasilitas pendidikan, pengadaan biaya pendidikan bagi pengembangan madrasah. ${ }^{14}$

Kedua, Sebagai Pendukung (Supporting Agency) Peran komite Madrasah Aliyah Negeri 2 Pamekasan sebagai pendukung (Supporting Agency) dalam penyelenggaraan pengembangan sarana prasarana pendidikan dapat berupa dukungan financial, tenaga, dan dukungan pemikiran. Secara riil pemberian dukungan yang diberikan komite madrasah bisa diwujudkan dengan pemecahan masalah atas kekurangan sarana prasarana pendidikan yang tidak termasuk dalam anggaran dana BOS, keringanan biaya madrasah bagi anak yang kurang mampu, serta dukungan tenaga. Misalnya ikut memperbaiki jika ada gedung madrasah yang rusak.

Temuan penelitian menunjukkan bahwa komite MAN 2 Pamekasan dalam membantu mengembangkan sarana prasarana disini menarik sumbangan kepada orangtua siswa untuk membantu mengembangkan sarana prasarana. Karena keterbatasan dana dari pemerintah maka komite madrasah yang menjadi solusinya dengan berupaya mengadakan sumbangan bulanan dari orangtua siswa yang dikenal sebagai istilah infaq bulanan yang diperuntukkan untuk pengadaan sarana prasarana berskala kecil seperti meja, kursi siswa. Ada juga sumbangan infaq insidentil setahun sekali yang merupakan kesepakatan dari wali santri untuk memenuhi kebutuhan yang berskala besar seperti pembangunan kelas baru.

Berdasarkan temuan tersebut Hasbullah dalam bukunya yang menyatakan bahwa komite madrasah berfungsi dalam Menggalang dana masyarakat dalam rangka pembiayaan penyelenggaraan pendidikan di madrasah. ${ }^{15}$

Peran sebagai pendukung yang dipegang oleh komite madrasah tidak hanya menjadikannya sebatas hanya pemberi dorongan dan motivasi, akan tetapi harus lebih dari itu. Dengan memegang peranan sebagai sebagai supporting agency komite madrasah juga bisa mendorong dan memberi kesadaran kepada orang tua dan masyarakat untuk selalu berpartisipasi dalam dunia pendidikan.

14 Syaiful Sagala, Manajemen Strategik dalam Peningkatan Mutu Pendidikan (Bandung: Alfabeta, 2007), 242.

15 Hasbullah, Otonomi Pendidikan: Kebijakan Otonomi Daerah dan Implikasinya terhadap Penyelenggaraan Pendidikan (Jakarta: PT Raja Grafindo Persada, 2007), 93-94. 
Ketiga, Sebagai pengontrol (controlling agency), komite MAN 2 Pamekasan Dalam ikut berpartisipasi untuk membantu mengembangkan sarana prasarana madrasah, pada saat rapat perencanaan pengadaan sarana prasarana madrasah dilibatkan sebagai perwakilan dari masyarakat dan orangtua santri. Dalam proses perencanaan ini bentuk pengawasan yang diberikan adalah mengawasi pelaksanaan dari RAPBS dan ikut berpartisipasi dalam pembuatan skala prioritas yang dibutuhkan madrasah mulai dari penyusunan barang-barang yang dibutuhkan sampai dengan berapa biaya yang dibutuhkan dalam memenuhi kebutuhan tersebut.

Selain itu, Komite madrasah Aliyah Negeri 2 Pamekasan dalam controlling pengadaan sarana prasarana salah satu bentuk pengawasan yang diberikan yaitu pihak komite madrasah terlibat langsung dalam panitia pengadaan sarana prasarana madrasah. Karena jika komite madrasah sudah terlibat langsung bersama dengan perwakilan guru yang menjadi panitia pelaksana pengadaan sarana prasarana, maka dengan maksimal bisa mengawasi jalannya proses pengadaan sarana prasarana di madrasah seperti pembangunan gedung, pembelian peralatan, perbaikan lantai jika rusak, dan lain sebagainya.

Semua kegiatan, program maupun proses memang harus diawasi dalam pelaksanaannya untuk menghindari terjadinya penyelewengan, termasuk juga dalam proses pengembangan sarana prasarana. Komite MAN 2 Pamekasan sudah menjalankan perannya sebagai pengawas terhadap pengadaan sarana prasarana.

Keempat, Sebagai mediator, komite madrasah di MAN 2 Pamekasan sebagai mediator dilihat dari usahanya setiap awal bulan mengadakan pertemuan dengan wali santri dengan tujuan untuk menampung semua masukan/aspirasi dari wali santri yang nantinya akan disampaikan kepada pihak madrasah sebagai bentuk koreksi madrasah. peran komite madrasah Ssbagai mediator, komite madrasah menjadi pihak yang menjembatani antara madrasah dengan masyarakat.

Dalam proses pengadaan sarana prasarana sebagai bentuk pengembangan madrasah, komite madrasah menjadi penghubung antara madrasah dan wali santri dalam proses penarikan sumbangan dana untuk mengembangkan sarana prasarana. Misalnya, pembangunan gedung baru dan perbaikan gedung.

Komite madrasah di MAN 2 Pamekasan selalu mendorong tumbuhnya perhatian masyarakat akan pentingnya pendidikan, sehingga masyarakat terutama wali santri berkomitmen dalam usaha memberi sumbangsih berupa financial maupun materil dalam usaha ikut berpartisipasi mengembangkan sarana prasarana di madrasah ini. Kerjasama antara komite madrasah dengan masyarakat sangat terjalin dengan baik dibuktikan dengan diadakannya pertemuan wali santri setiap bulan.

Temuan penelitian tersebut sejalan dengan pendapat Hasbullah dalam bukunya dimana salah satunya komite madrasah dalam menjalankan tugasnya berupaya mendorong tumbuhnya perhatian dan komitmen masyarakat terhadap penyelenggaraan pendidikan yang bermutu di madrasah. ${ }^{16}$

Adanya komite madrasah harus bertumpu atas landasan partisipasi masyarakat dalam rangka meningkatkan kualitas pendidikan. Untuk itu, pembentukannya harus memperhatikan tugas sesuai kedudukan dan otonomi yang ada. Sebagaimana pendapat abdul rahmat dalam bukunya tugas komite madrasah sebagai pemberi

16 Hasbullah, Otonomi Pendidikan (Jakarta: PT Raja Grafindo Persada, 2006), 93-94. 
pertimbangan, sebagai badan pendukung, sebagai pengontrol dan terakhir sebagai mediator. ${ }^{17}$

\section{Implikasi Pengembangan Sarana Prasarana bagi Keberlangsungan Pendidikan di MAN 2 Pamekasan}

Dari adanya komite dalam membantu mengembangkan sarana prasarana harapan MAN 2 Pamekasan berimplikasi positif pada madrasah. peningkatan kualitas sarana prasarana merupakan implikasi dari adanya komite dalam membantu mengembangkan sarana prasarana sehingga proses pembelajaran berjalan secara optimal.

Sarana prasarana adalah suatu komponen penting yang tidak bisa terpisahkan dari proses pendidikan dan perlu mendapatkan perhatian yang lebih dari para manajer pendidikan. Karena sarana prasarana pendidikan jika terpenuhi dengan sempurna maka akan membantu dalam menunjang efektif dan efisiennya penyelenggaraan pendidikan. Mulyasa dalam bukunya menyatakan:

Sarana pendidikan merupakan perlengkapan dan peralatan yang secara langsung digunakan dan menunjang proses pendidikan, khususnya dalam proses belajar mengajar seperti gedung, kursi dan meja, serta alat-alat dan media pembelajaran. Sedangkan prasarana pendidikan merupakan fasilitas pembelajaran yang secara tidak langsung menunjang akan jalannya proses pengajaran, misalnya taman, halaman, lapangan olahraga dan lain-lain. Komponen-komponen tersebut merupakan prasarana pendidikan. ${ }^{18}$

Sebagai komponen penunjang dari suatu pembelajaran, madrasah harus menyediakan sarana dan prasarana yang memenuhi standar nasional yang sudah ditetapkan oleh pemerintah. Kelengkapan sarana prasarana perlu diperhatikan secara optimal karena berpengaruh terhadap keberhasilan proses kegiatan belajar mengajar di madrasah. ${ }^{19}$

Sarana Prasarana yang ada di MAN 2 Pamekasan sudah lengkap tetapi masih belum sempurna. Bisa dikatakan sesuai standarisasi karena sudah melebihi ketentuan minimum yang dikeluarkan oleh pemerintah. MAN 2 Pamekasan memiliki ruang kelas, perpustakaan, lab IPA (biologi, fisika, kimia, komputer, bahasa), ruang pimpinan, ruang guru, ruang tata usaha, tempat beribadah, ruang $\mathrm{BK}$, UKS, ruang Osis, gudang, ruang sirkulasi, tempat bermain dan berolahraga dan prasarana penunjang lainnya yang datanya akan dilampirkan. Oleh karena itu, madrasah dikatakan bermutu apabila bisa memenuhi standarisasi sarana prasarana sesuai dengan peraturan pemerintah. ${ }^{20}$

17 Abdul Rahmat, Manajemen Humas Sekolah (Yogyakarta: Media Akademi, 2016), 107.

18 Mulyasa, Manajemen Administrasi \& Organisasi Pendidikan (Yogyakarta: Ar-Ruzz Media, 2017), 17.

19 Selvi Mayarani \& Desi Nurhikmahyanti, "Peran Komite Sekolah dalam Pengadaan Sarana dan Prasarana di SD Negeri Pucang IV Sidoarjo", Jurnal Inspirasi Manajemen Pendidikan. 4 (April 2014), 163.

20 Subarniyati, Manajemen Kepala Madrasah dan Peran Komite dalam Peningkatan Mutu Pendidikan di Madrasah Ibtidaiyah Ma'arif Giriloyo. Thesis. (Yogyakarta: UIN Sunan Kalijaga, 2018). 2. 


\section{KESIMPULAN}

Setelah diuraikan berbagai data hasil penelitian yang sudah diaksanakan oleh peneliti maka kesimpulan yang bisa diambil sebagai berikut:

Konsep Komite Madrasah dalam Membantu Mengembangkan Sarana Prasarana di MAN 2 Pamekasan setelah dibentuk maka komite di MAN 2 Pamekasan menetapkan tujuan, setelah itu perencanaan awal tahun dan membuat program kerja selama satu tahun kedepan.

Pelaksanaan Program Komite Madrasah Aliyah Negeri 2 Pamekasan dengan menjalankan perannya sebagai Sebagai pemberi pertimbangan (advisory agency),Pertimbangan yang diberikan oleh komite madrasah berupa:Pemikiran/ide, dan saran, Pertimbangan tentang cara yang digunakan dalam pengadaan sarana prasarana yang berhubungan langsung maupun tidak langsung terhadap peningkatan kualitas pendidikan, Menetapkan RAPBS, Membantu menentukan skala prioritas, 2) Sebagai Pendukung (Supporting Agency) Komite madrasah di MAN 2 Pamekasan sebagai pendukung dalam hal membantu mengembangkan sarana prasarana berupa:Dukungan financial, tenaga dan pikiran. Membantu dalam perbaikan gedung.Melakukan penggalangan dana kepada orang tua santri, 3) Sebagai pengontrol (controlling agency) Komite Madrasah Aliyah Negeri 2 Pamekasan sebagai pengontrol dalam hal:Terlibat langsung dalam panitia pengadaan sarana prasarana madrasah,Mengontrol terhadap pelaksanaan RAPBS dan yang terpenting dalam pengembangan fasilitas sarana prasarana madrasah, Mengontrol keadaan sarana prasarana di madrasah, 4) Sebagai mediator Komite Madrasah Aliyah Negeri 2 Pamekasan sebagai mediator dalam hal: Menampung aspirasi dari masyarakat, Mensosialisasikan program madrasah kepada wali santri, Meningkatkan Partisipasi Masyarakat terhadap Madrasah

Implikasi Pengembangan Sarana Prasarana bagi Keberlangsungan Pendidikan di MAN 2 Pamkasan yaitu Sarana Prasarana yang ada di MAN 2 Pamekasan mengalami peningkatan dan sudah lengkap tetapi masih belum sempurna. Bisa dikatakan sesuai standarisasi karena sudah melebihi ketentuan minimum yang dikeluarkan oleh pemerintah. MAN 2 Pamekasan memiliki ruang kelas, perpustakaan, lab IPA (biologi, fisika, kimia, komputer, bahasa), ruang pimpinan, ruang guru, ruang tata usaha, tempat beribadah, ruang BK, UKS, ruang OSIS, gudang, ruang sirkulasi, tempat bermain dan berolahraga dan prasarana penunjang lainnya.

\section{DAFTAR PUSTAKA}

Atiqullah, and Milda Karya Puspasari. "STRATEGI MANAJEMEN PERUBAHAN DALAM MENINGKATKAN KUALITAS MANAJERIAL PENDIDIKAN ISLAM DI MAN 1 PAMEKASAN." Re-JIEM (Research Journal of Islamic Education Management) 1, no. 2 (2018). https://doi.org/https://doi.org/10.19105/rjiem.v1i2.2088.

Bafadal, Ibrahim, Manajemen Perlengkapan Sekolah: Teori dan Aplikasinya. Jakarta: Bumi Aksara, 2010.

Hadis, Abdul \& Nurhayati, Manajemen Mutu Pendidikan. Bandung: Alfabeta, 2010.

Hasbullah, Otonomi Pendidikan; Kebijakan Otonomi Daerah dan Implikasinya terhadap Penyelenggaraan Pendidikan. Jakarta: PT RajaGrafindo Persada, 2007.

Hidayat, Ara \& Imam Machali, Pengelolaan Pendidikan: Konsep, Prinsip, dan Aplikasi dalam Mengelola Sekolah dan Madrasah. Yogyakarta: Kaukaba, 2012. 
Matin, Manajemen Sarana Prasarana. Jakarta: PT Raja Grafindo, 2017.

Mayarani, Selvi \& Desi Nurhikmahyanti, "Peran Komite Sekolah dalam Pengadaan Sarana dan Prasarana di SD Negeri Pucang IV Sidoarjo", Jurnal Inspirasi Manajemen Pendidikan. 4 (April 2014).

Meleong, J. Lexy. Metode Penelitian Kualitatif . Bandung: Rosdakarya, 2005.

Mulyasa. Manajemen Administrasi \& Organisasi Pendidikan. Yogyakarta: Ar-Ruzz Media, 2017.

Mulyono. Manajemen Administrasi dan Organisasi Pendidikan. Jogjakarta: Ar-Ruzz Media, 2014.

Rahmat, Abdul. Manajemen Humas Sekolah. Yogyakarta: Media Akademi, 2016.

Sagala, Syaiful. Manajemen Strategik dalam Peningkatan Mutu Pendidikan. Bandung: Alfabeta, 2007.

Strauss, Anselm dan Juliet Corbin, Dasar-dasar Penelitian Kualitatif . Yogyakarta: Pustaka Pelajar, 2005.

Subarniyati, Manajemen Kepala Madrasah dan Peran Komite dalam Peningkatan Mutu Pendidikan di Madrasah Ibtidaiyah Ma'arif Giriloyo. Thesis. Yogyakarta: UIN Sunan Kalijaga, 2018.

Widyaningsih, Eni. "Peran Komite Sekolah dalam Pengelolaan Sarana Prasarana Pembelajaran di SDN Serayu", Jurnal Pendidikan Guru Sekolah Dasar. 10 (2016). 